\title{
Article \\ The Effect of Mouthrinse with $0.05 \%$ Dexamethasone Solution on the Oral Bacterial Community of Oral Lichen Planus Patients: Prospective Pilot Study
}

\author{
Jeong-Kui Ku ${ }^{1} \mathbb{D}$, Shin-Young Park ${ }^{2}$, Kyung-Gyun Hwang ${ }^{3 \oplus}$ and Pil-Young Yun ${ }^{4, *}$ \\ 1 Department of Oral and Maxillofacial Surgery, Gangnam Severance Hospital, Yonsei University College \\ of Dentistry, 211 Eonju-ro, Gandnam-gu, Seoul 06273, Korea; KUJK@yuhs.ac \\ 2 Program of Dental Education, Department of Dental Science and Dental Research Institute, \\ School of Dentistry, Seoul National University, Seoul 03080, Korea; nalby99@snu.ac.kr \\ 3 Division of Oral and Maxillofacial Surgery, Department of Dentistry, College of Medicine, \\ Hanyang University, Seoul 04763, Korea; hkg@hanyang.ac.kr \\ 4 Department of Oral and Maxillofacial Surgery, Section of Dentistry, Seoul National University \\ Bundang Hospital, 82 Gumi-ro, 173 beon-gil, Bundang-gu, Seongnam 13620, Korea \\ * Correspondence: pilyoung@snubh.org; Tel.: +82-31-787-2780; Fax: +82-31-787-4068
}

check for updates

Citation: Ku, J.-K.; Park, S.-Y.; Hwang, K.-G.; Yun, P.-Y. The Effect of Mouthrinse with $0.05 \%$

Dexamethasone Solution on the Oral Bacterial Community of Oral Lichen Planus Patients: Prospective Pilot Study. Appl. Sci. 2021, 11, 6286. https://doi.org/10.3390/app11146286

Academic Editors: Paola Gandini and Andrea Scribante

Received: 25 May 2021

Accepted: 2 July 2021

Published: 7 July 2021

Publisher's Note: MDPI stays neutral with regard to jurisdictional claims in published maps and institutional affiliations.

Copyright: (c) 2021 by the authors. Licensee MDPI, Basel, Switzerland. This article is an open access article distributed under the terms and conditions of the Creative Commons Attribution (CC BY) license (https:// creativecommons.org/licenses/by/ $4.0 /)$.

\begin{abstract}
Few studies have already been performed to assess oral bacteria during steroid therapy for oral lichen planus (OLP). Thus, the aim of our study was to analyze the effect of dexamethasone mouthrinse treatment on the oral bacteria of OLP patients. This prospective study was conducted on patients who were diagnosed with OLP and treated with $0.05 \%$ dexamethasone mouthrinse twice per day for 4 weeks. Using unstimulated saliva of the patients before and after treatment, the qualitative and quantitative changes in oral bacteria were analyzed using quantitative real-time polymerase chain reaction (qPCR). The qPCR results were analyzed using Wilcoxon signed-rank test to the quantitative changes with dexamethasone mouthrinse. The statistical significance was considered at a level of 0.05 . In total, 20 patients were enrolled in this study, wherein all were noted to show improved symptoms of OLP. Fifteen patients (75\%) had a qualitative change in the oral microbial species and an improved relative periodontitis risk score (from $26.1 \pm 10.7$ to $20.9 \pm 9.2 ; p=0.008$ ). However, quantitative changes in all species were determined to be not statistically different before and after the treatment. Most OLP patients had a changed microbial community composition after $0.05 \%$ dexamethasone mouthrinse for 4 weeks. In particular, the composition of the periodontopathic bacteria was improved after the treatment.
\end{abstract}

Keywords: bacteria; culture technique; dentistry; oral lichen planus; real-time PCR; saliva; periodontology

\section{Introduction}

Oral lichen planus (OLP) has been identified as a relatively common chronic mucosal disease that occurs in $0.1-4 \%$ of the total population [1]. OLP patients usually often suffer from poor quality of life with psychological anxiety due to its symptoms, such as difficulty with pronunciation, swallowing, and tooth brushing [2]. Histological features of OLP include hyperkeratosis, destruction of basal cells and the basement membrane, T-lymphocyte infiltration in adjacent connective tissue, and the appearance of Civatte bodies [2]. In terms of these characteristics, the origin and development process of OLP has not yet been clearly elucidated. However, it has been revealed that OLP is an autoimmune disease in which an immunologically mediated attack by T-lymphocytes destroys keratinocytes [3].

Treatment of OLP cannot be focused on a specific target; therefore, it is limited to symptomatic treatment using immunomodulatory therapy. Steroid therapy has been most commonly used in symptomatic management, which includes topical application and 
gargling with dexamethasone, fluticasone propionate, and betamethasone sodium phosphate $[4,5]$. Glucocorticoids have potent anti-inflammatory properties showing a decrease in the number and function of various immune cells, such as T and B lymphocytes, monocytes, neutrophils, and eosinophils, as well as the production of cytokines, chemokines, and eicosanoids, and enhanced production of macrophage migration inhibitory factors [6].

When used to treat OLP, topical corticosteroids have been known to have fewer side effects and are comparably as effective as systemic corticosteroids [7]. However, long-term steroid gargles can affect the oral flora that, in turn, causes bacterial diseases, such as acute pseudomembranous candidiasis [7]. Therefore, plaque control and rigorous oral hygiene have been known as a fundamental requisite for the treatment of any oral disease [8]. Although González-García et al. reported a low risk of fungal over-infection with triamcinolone acetonide mouthrinse [9], a few studies have reported the change of oral flora after the use of steroid mouthrinse for treatment of OLP. We hypothesized that a characteristic bacterial species is activated in the saliva of OLP patients, and the microbial community composition changes during steroid gargles. Thus, this study aimed to analyze the qualitative and quantitative changes in oral bacteria using quantitative real-time polymerase chain reaction (qPCR) in the saliva of OLP patients who were treated with dexamethasone gargle for 4 weeks.

\section{Materials and Methods}

\subsection{Patients}

This prospective study was conducted on patients who were diagnosed with OLP and treated with $10 \mathrm{~mL}$ of $0.05 \%$ dexamethasone gargle twice per day. OLP was diagnosed in patients with hypersensitivity to hot or spicy food, and reticular-patterned, atrophic, and white lesions in the oral cavity by an expert clinician with $\geq 23$ experience. This study was reviewed and approved by the Institutional Review Board at Seoul National University Bundang Hospital (No. B-1704-393-305). All patients were informed about the conducting of this study and agreed in writing to participate.

The inclusion criteria were as follows: (1) age over 18 years; (2) informed consent from voluntary participants; (3) self-managing oral hygiene with a pocket depth of teeth within 1-3 mm without calculus or gingivitis; and (4) dexamethasone gargle use for only 4 weeks. On the other hand, the exclusion criteria were as follows: (1) lack of agreement to participate in the study; (2) a history of steroid treatment within 3 months before the start of the study; (3) a history of systemic or local antibiotics within 3 months before the start of the study; (4) untreated periodontitis or dental caries; (5) current smoker; and (6) uncontrolled systemic diseases or the presence of a dentofacial-related deformity or syndrome.

\subsection{Saliva Analysis}

Unstimulated saliva was collected from the 28 patients before treatment with dexamethasone gargle, and after 4 weeks of treatment, unstimulated saliva was collected again for analysis. The saliva samples were collected via $10 \mathrm{~mL}$ of EasyGen mouth rinse (YD Global Lifescience, Seongnam-si, Gyeonggi-do, Korea). All participants gargled for $20 \mathrm{~s}$ using mouthwash, and the samples were collected into a specimen bucket. DNA extraction was conducted using a QIAamp DNA Mini Kit (QIAGEN, Hilden, Germany) [10]. The DNA extraction was performed according to the manufacturer's instructions.

\subsection{Multiplex Quantitative Real-Time Polymerase Chain Reaction (qPCR)}

qPCR was performed according to the manufacturer's instructions using an EasyPerio (YD Global Lifescience, Seongnam-si, Gyeonggi-do, Korea) that consisted of Oligo Mix, $2 \times$ Master mix. The PCR mixture was prepared using $9 \mu \mathrm{L}$ of Oligo Mix, $10 \mu \mathrm{L}$ of $2 \times$ Master Mix, and $1 \mu \mathrm{L}$ of template DNA. The CFX96 Touch ${ }^{\mathrm{TM}}$ Real-Time PCR Detection System (Bio-Rad, Hercules, CA, USA) was used for qPCR. The PCR conditions were as follows: pre-denaturation for $30 \mathrm{~s}$ at $95^{\circ} \mathrm{C}$, followed by 40 cycles of $5 \mathrm{~s}$ denaturation at $95^{\circ} \mathrm{C}$, and $30 \mathrm{~s}$ extension and annealing at $62^{\circ} \mathrm{C}$. Scanning of fluorescence was performed after the 
extension and annealing processes. According to the bacterial species, the results of qPCR were calculated with a relative fluorescence unit (RFU) and classified into Porphyromonas gingivalis (Pg), Tannerella forsythia (Tf), Treponema denticola (Td), Fusobacterium nucleatum (Fn), Prevotella intermedia (Pi), Prevotella nigrescens (Pn), Streptococcus mitis (Sm), Streptococcus mutans (Smu), and Streptococcus sobrinus (Ss).

Considering the ecological proportion of bacterial populations according to periodontal health [11], the EasyPerio automatically calculated the relative periodontitis risk score (PR-score) and caries risk score (CR-score) [12]. The data were analyzed with sequenceddetection system software (ABI 7500 Fast Real-Time PCR System, version 1.4.1., Applied Biosystems, Life Technologies Inc., Forest City, IA, USA). The threshold cycle values were measured using standard curves for the number of bacterial cells from known amounts of bacterial-specific DNA.

\subsection{Statistical Analysis}

The qPCR results were compared to the quantitative changes before and after dexamethasone treatment using Wilcoxon signed-rank test. In addition, absolute quantitative changes were compared to analyze the effect of dexamethasone on oral microflora. Data are presented as mean \pm standard deviation, and statistical analysis was performed using SPSS 25.0 for Windows (SPSS Inc., Chicago, IL, USA). Significance was considered at a level of 0.05 .

\section{Results}

We enrolled 28 patients in this study, of whom eight were excluded because of insufficient saliva secretion or poor quality of the saliva sample ( 1 male, 19 females; age $61.1 \pm 11.8$ years) (Figure 1).

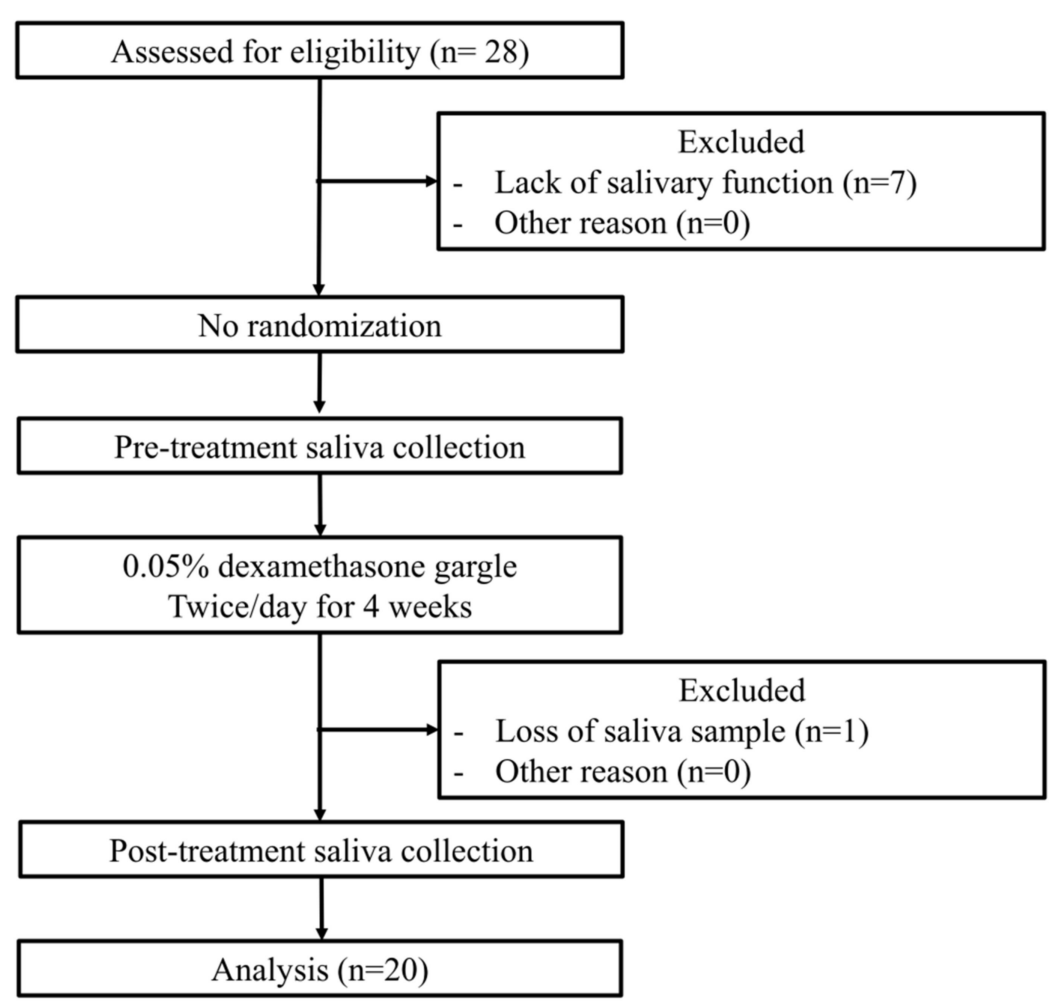

Figure 1. Flow diagram of the exclusion and research steps.

All patients showed improved symptoms of OLP after four weeks of dexamethasone gargling, whereas 15 of the 20 patients (75\%) showed qualitative changes in oral microbial species after 4 weeks of dexamethasone gargle (Table 1). After steroid therapy, the detection 
frequency was decreased for four microbial species: $\operatorname{Tf}(65 \%$ to $50 \%)$, Td (15\% to $10 \%)$, Pi ( $30 \%$ to $15 \%)$, and $\operatorname{Pn}(75 \%$ to $55 \%)$. Furthermore, the detection frequency was maintained for the other four species: Pg (55\%), Fn (100\%), Sm (100\%), and Smu (40\%; Table 1).

Table 1. Demographic information and qualitative changes in the oral bacterial species of the oral lichen planus patients before and after the treatment with dexamethasone gargle.

\begin{tabular}{|c|c|c|c|c|c|c|c|c|c|c|c|c|}
\hline \multirow{2}{*}{ Patient Number } & \multirow{2}{*}{ Age } & \multirow{2}{*}{ Sex } & \multicolumn{10}{|c|}{ Qualitative Results of Oral Bacterial Species } \\
\hline & & & $P g$ & $T f$ & $T d$ & $F n$ & $P i$ & $P n$ & $S m$ & Smu & Ss & Change \\
\hline$\# 1$ & 58 & $\mathrm{~F}$ & $\mathrm{~N}$ & $\mathrm{P}$ & $\mathrm{N}$ & $\mathrm{P}$ & $\mathrm{N}$ & - & $\mathrm{P}$ & $\mathrm{P}$ & - & - \\
\hline$\# 2$ & 67 & $\mathrm{~F}$ & - & $\mathrm{P}$ & $\mathrm{N}$ & $\mathrm{P}$ & $\mathrm{N}$ & $\mathrm{P}$ & $\mathrm{P}$ & $\mathrm{P}$ & $\mathrm{N}$ & $\bullet$ \\
\hline \#3 & 81 & $\mathrm{~F}$ & $\mathrm{~N}$ & $\mathrm{~N}$ & $\mathrm{~N}$ & $\mathrm{P}$ & $\mathrm{N}$ & $\mathrm{N}$ & $\mathrm{P}$ & $\mathrm{N}$ & $\mathrm{N}$ & \\
\hline$\# 4$ & 70 & F & $\mathrm{P}$ & $\mathrm{P}$ & + & $\mathrm{P}$ & $\mathrm{N}$ & - & $\mathrm{P}$ & $\mathrm{N}$ & $\mathrm{N}$ & • \\
\hline \#5 & 72 & F & $\mathrm{P}$ & $\mathrm{P}$ & $\mathrm{N}$ & $\mathrm{P}$ & $\mathrm{N}$ & $\mathrm{P}$ & $\mathrm{P}$ & $\mathrm{N}$ & $\mathrm{N}$ & \\
\hline \#6 & 67 & F & $\mathrm{P}$ & $\mathrm{N}$ & $\mathrm{N}$ & $\mathrm{P}$ & - & $\mathrm{P}$ & $\mathrm{P}$ & $\mathrm{P}$ & $\mathrm{N}$ & • \\
\hline \#7 & 68 & $\mathrm{~F}$ & $\mathrm{P}$ & $\mathrm{P}$ & $\mathrm{N}$ & $\mathrm{P}$ & $\mathrm{N}$ & $\mathrm{P}$ & $\mathrm{P}$ & + & $\mathrm{N}$ & • \\
\hline$\# 8$ & 54 & F & $\mathrm{P}$ & $\mathrm{P}$ & $\mathrm{P}$ & $\mathrm{P}$ & - & $\mathrm{P}$ & $\mathrm{P}$ & $\mathrm{N}$ & $\mathrm{N}$ & • \\
\hline \#9 & 73 & F & $\mathrm{P}$ & $\mathrm{N}$ & $\mathrm{N}$ & $\mathrm{P}$ & $\mathrm{N}$ & $\mathrm{N}$ & $\mathrm{P}$ & $\mathrm{P}$ & $\mathrm{N}$ & \\
\hline$\# 10$ & 59 & F & + & + & $\mathrm{N}$ & $\mathrm{P}$ & - & $\mathrm{N}$ & $\mathrm{P}$ & $\mathrm{N}$ & $\mathrm{N}$ & • \\
\hline \#11 & 39 & $\mathrm{~F}$ & $\mathrm{~N}$ & $\mathrm{P}$ & $\mathrm{N}$ & $\mathrm{P}$ & $\mathrm{N}$ & $\mathrm{P}$ & $\mathrm{P}$ & $\mathrm{P}$ & $\mathrm{N}$ & \\
\hline \#12 & 60 & F & $\mathrm{P}$ & $\mathrm{P}$ & - & $\mathrm{P}$ & $\mathrm{P}$ & - & $\mathrm{P}$ & $\mathrm{P}$ & - & • \\
\hline$\# 13$ & 56 & F & $\mathrm{N}$ & $\mathrm{P}$ & $\mathrm{N}$ & $\mathrm{P}$ & $\mathrm{N}$ & $\mathrm{P}$ & $\mathrm{P}$ & $\mathrm{N}$ & $\mathrm{N}$ & \\
\hline \#14 & 56 & $\mathrm{~F}$ & $\mathrm{~N}$ & - & $\mathrm{N}$ & $\mathrm{P}$ & $\mathrm{N}$ & $\mathrm{P}$ & $\mathrm{P}$ & $\mathrm{N}$ & $\mathrm{N}$ & • \\
\hline$\# 15$ & 59 & F & + & - & - & $\mathrm{P}$ & $\mathrm{N}$ & - & $\mathrm{P}$ & $\mathrm{N}$ & $\mathrm{N}$ & • \\
\hline$\# 16$ & 72 & $\mathrm{~F}$ & $\mathrm{P}$ & $\mathrm{N}$ & $\mathrm{N}$ & $\mathrm{P}$ & $\mathrm{P}$ & + & $\mathrm{P}$ & $\mathrm{N}$ & $\mathrm{N}$ & • \\
\hline$\# 17$ & 73 & $\mathrm{M}$ & $\mathrm{P}$ & $\mathrm{N}$ & $\mathrm{N}$ & $\mathrm{P}$ & $\mathrm{N}$ & $\mathrm{N}$ & $\mathrm{P}$ & $\mathrm{P}$ & $\mathrm{N}$ & \\
\hline \#18 & 53 & $\mathrm{~F}$ & $\mathrm{~N}$ & $\mathrm{~N}$ & $\mathrm{~N}$ & $\mathrm{P}$ & $\mathrm{P}$ & - & $\mathrm{P}$ & $\mathrm{N}$ & $\mathrm{N}$ & • \\
\hline \#19 & 33 & $\mathrm{~F}$ & - & - & $\mathrm{N}$ & $\mathrm{P}$ & $\mathrm{N}$ & $\mathrm{P}$ & $\mathrm{P}$ & $\mathrm{N}$ & $\mathrm{N}$ & • \\
\hline \#20 & 52 & F & $\mathrm{N}$ & - & $\mathrm{N}$ & $\mathrm{P}$ & $\mathrm{N}$ & $\mathrm{P}$ & $\mathrm{P}$ & - & $\mathrm{N}$ & • \\
\hline
\end{tabular}

Pg, Porphyromonas gingivalis; Tf, Tannerella forsythia; Td, Treponema denticola; Fn, Fusobacterium nucleatum; Pi, Prevotella intermedia; Pn, Prevotella nigrescens; Sm, Streptococcus mitis; Smu, Streptococcus mutans; Ss, Streptococcus sobrinus, P: positive, N: negative, + : change from negative to positive, -: change from positive to negative. $\bullet$ : Change in more than one species.

The PR scores significantly reduced by $5.2 \pm 7.5$ after the treatment (from $26.1 \pm 10.7$ to $20.9 \pm 9.2, p=0.008$ ). The $C R$ scores decreased by $1.8 \pm 6.8$ after the treatment (from $23.1 \pm 9.5$ to $21.3 \pm 5.8$ ) without significance ( $p=0.492$; Figure 2 ).

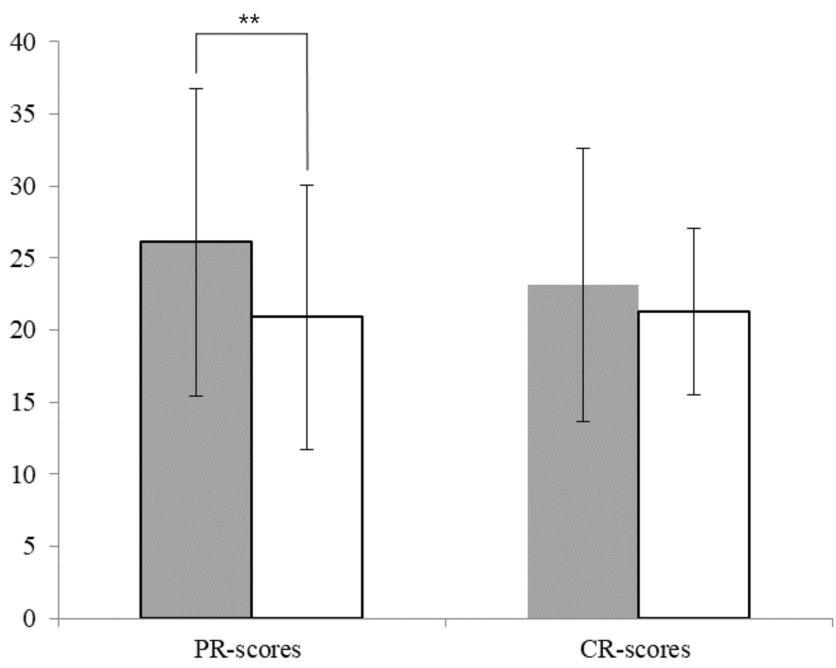

口Before the treatment

$\square$ After the treatment

Figure 2. The relative periodontitis and caries risk scores after 4 weeks of dexamethasone treatment. (**: Wilcoxon signed-rank test significance level at 0.01 ; CR-score, relative caries risk score; PR-score, relative periodontitis risk score). 
The absolute quantitative changes of oral microbial species were significant except for Td and Ss $(0.7 \pm 1.5,104 \mathrm{RFU}$ and $0.5 \pm 1.9,105 \mathrm{RFU}$, respectively; Table 2). The average quantitative changes in oral microbial species were reduced except for $\mathrm{Td}$ and $\mathrm{Pn}$ $(0.1 \pm 1.7$ and $0.0 \pm 1.7,104 \mathrm{RFU}$, respectively). However, the quantitative changes were not statistically significantly different before and after the treatment (Figure 3, Supplementary Table S1).

Table 2. Absolute quantitative changes in the oral microbial species of oral lichen planus patients before and after treatment with dexamethasone gargle.

\begin{tabular}{|c|c|c|c|c|c|c|c|c|c|}
\hline \multirow[b]{2}{*}{ Patient Number } & \multicolumn{9}{|c|}{ Relative Fluorescence Unit (RFU) } \\
\hline & $\begin{array}{c}P g \\
\left(10^{5}\right)\end{array}$ & $\begin{array}{c}T f \\
\left(10^{5}\right)\end{array}$ & $\begin{array}{c}T d \\
\left(10^{4}\right)\end{array}$ & $\begin{array}{c}F n \\
\left(10^{6}\right)\end{array}$ & $\begin{array}{c}P i \\
\left(10^{6}\right)\end{array}$ & $\begin{array}{c}P n \\
\left(10^{4}\right)\end{array}$ & $\begin{array}{c}S m \\
\left(10^{6}\right)\end{array}$ & $\begin{array}{l}S m u \\
\left(10^{5}\right)\end{array}$ & $\begin{array}{c}S s \\
\left(10^{5}\right)\end{array}$ \\
\hline Total & $1.5(2.1)$ & $1.5(1.8)$ & $0.7(1.5)$ & $1.2(1.7)$ & $1.1(2.2)$ & $1.1(1.2)$ & $2.5(2.8)$ & $1.2(1.5)$ & $0.5(1.9)$ \\
\hline$p$-value * & 0.001 & 0.002 & 0.068 & 0.000 & 0.018 & 0.001 & 0.000 & 0.008 & 0.180 \\
\hline
\end{tabular}

$\mathrm{Pg}$, Porphyromonas gingivalis; Tf, Tannerella forsythia; Td, Treponema denticola; Fn, Fusobacterium nucleatum; Pi, Prevotella intermedia; Pn, Prevotella nigrescens; Sm, Streptococcus mitis; Smu, Streptococcus mutans; Ss, Streptococcus sobrinus. *: Wilcoxon signed-rank test.

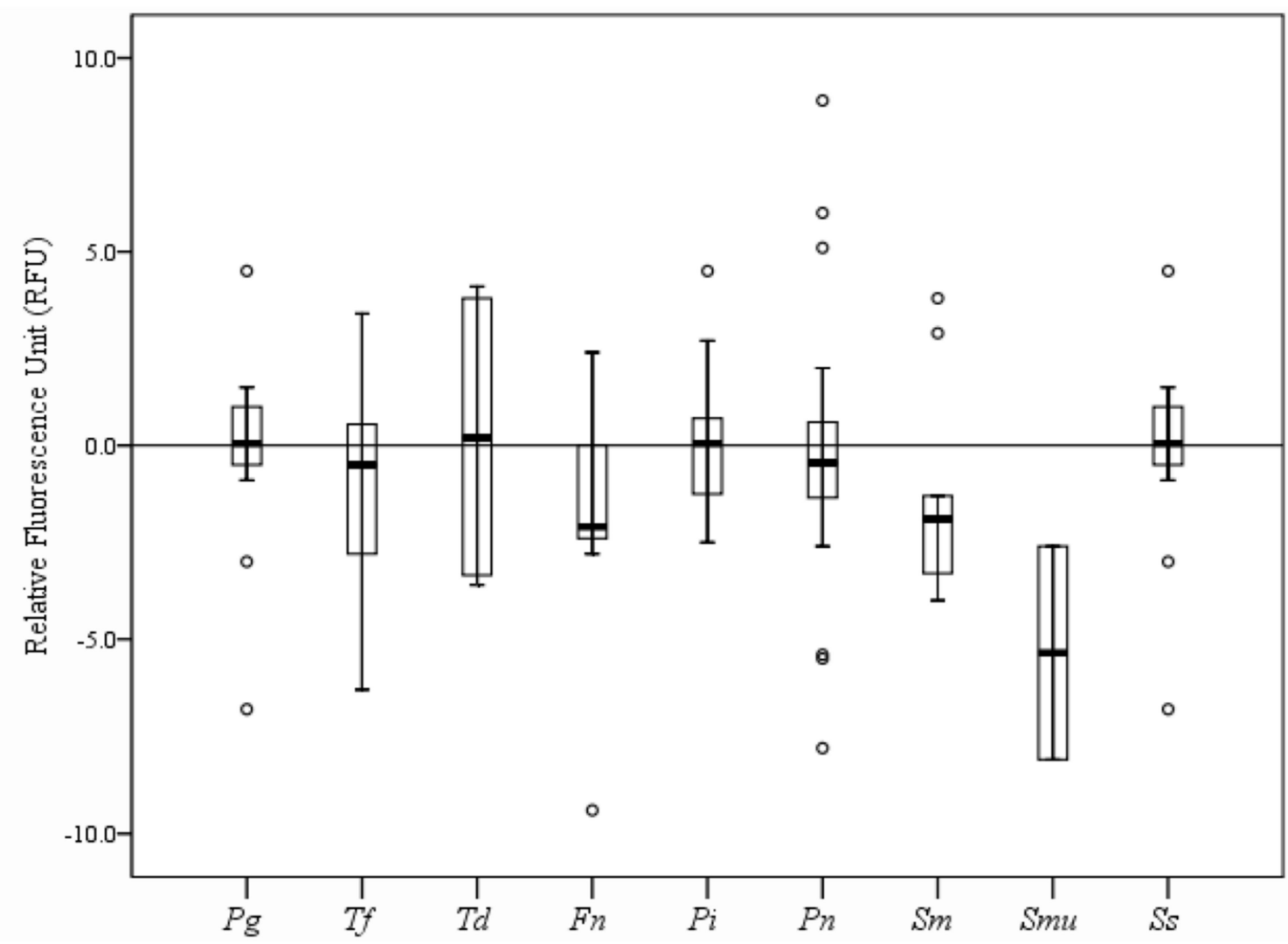

Figure 3. Quantitative changes in oral microbial species in OLP patients after 4 weeks of dexamethasone gargle. (Pg: Porphyromonas gingivalis, $10^{5}$ RFU; Tf: Tannerella forsythia, $10^{5}$ RFU; Td: Treponema denticola, $10^{4}$ RFU; Fn: Fusobacterium nucleatum, $10^{6}$ RFU; Pi: Prevotella intermedia, $10^{6}$ RFU; Pn: Prevotella nigrescens, $10^{4}$ RFU; Sm: Streptococcus mitis, $10^{6}$ RFU; Smu: Streptococcus mutans, $10^{5} \mathrm{RFU}$; Ss: Streptococcus sobrinus, $\left.10^{5} \mathrm{RFU}\right)$.

\section{Discussion}

In this study, we analyzed the qualitative and quantitative changes in oral bacteria of OLP patients. After 4 weeks of corticosteroid gargle use, $75 \%$ of the OLP patients had a changed microbial community composition. The amount of change was significant except for Treponema denticola and Streptococcus sobrinus. Overall, the total number of microbes appeared to decrease, but there was no consistent result for all patients or bacterial species. 
In the human oral cavity, about 700 bacterial species of phylogenies are identified as essential for maintaining a healthy condition, but some oral pathogens may exert the ability to differently trigger the activation of local immune responses with an imbalance of pro-inflammatory and anti-inflammatory gene responses [13-15]. The effect of the oral microbial population has not yet been clarified in the development of OLP, which is considered an oral immune disease. Lundstrom et al. first reported in 1984 that $37-50 \%$ of OLP patients had candidiasis [16]. Until 2000, Helicobacter pylori was the only bacterium believed to be attributed to OLP $[17,18]$. In 2008, Bornstein et al. showed high bacterial counts of Bacteroides ureolyticus, Dialister species, Staphylococcus haemolyticus, and Streptococcus agalactiae in OLP lesions by using a closed-format checkerboard DNA-DNA hybridization method [19]. In this present study, $F n$ and $S m$ were detected in all OLP patients, and the other species were observed in the following order: $\mathrm{Pn}(75 \%), \mathrm{Tf}(65 \%), \mathrm{Pg}(55 \%), \mathrm{Smu}$ (40\%), Pi (30\%), $\mathrm{Td}(15 \%)$, and $S s(10 \%)$. However, the relationship could not be elucidated between OLP development and microbial species because no comparison was made with healthy patients without OLP.

Although OLP is associated with T-lymphocytes without bacterial infection, it can be affected by oral pathogens that secrete endotoxins and stimulate the immune system [2]. In 1990, Holmstrup et al. found that intensive oral hygiene management improved symptoms in patients with atrophic and ulcerative OLP [20]. In 2007, chlorhexidine treatment was shown to significantly relieve the symptoms of OLP [21]. These reports suggested that the oral microbial community may interact with the symptoms or development of OLP.

On the other hand, immunomodulatory activity can affect the oral microbial community while suppressing the immunologic system during OLP treatment. In 2020, a systematic review revealed that systemic steroid was associated with the incidence of periodontal disease [22]. Even though steroid gargle has fewer side effects than systemic steroids, the possibility has been suggested that there could be a change in the composition of the microbial community during steroid mouthrinse therapy [7]. However, there has been a lack of study for indigenous bacterial populations with steroid gargles. As per our findings, $75 \%$ of patients had an altered oral microbial composition during 4 weeks of dexamethasone mouthrinse. These results suggest that the distribution of commensal bacteria could be affected by the steroid gargle and might be associated with the possibility of an individual to dental caries and periodontal disease.

Oral bacteria can be classified into periodontopathic and cariogenic bacteria. Among them, EasyPerio (YD Global Lifescience, Seongnam-si, Gyeonggi-do, Republic of Korea) can detect six periodontopathic $(P g, T f, T d, F n, P i$, and $P n)$ and two cariogenic ( $S m$ and $\mathrm{Smu}$ ) species. In particular, the dexamethasone mouthrinse significantly affected periodontopathic bacteria, but not cariogenic bacteria, as shown in Figure 1. Qualitatively, the four species reduced the frequency of detection, that is, $T f, P i, P n, T d$, and $S s$, and the others remained the same, i.e., $P g, F n, S m$, and $S m u$. Quantitatively, the absolute amount of the bacteria was significantly changed, or the six species $(P g, T f, F n, P i, P n, S m$, and $S m u$ ) were changed, except for $T d$ and $S$ s. However, the tendency of the increase or decrease in the number of bacteria was different for each patient; thus, the total number of bacteria showed no statistical difference among all patients.

Based on a recent advent of high-throughput sequencing technology, many researchers have tried to demonstrate the profiles of the bacterial community associated with OLP to determine the role of bacterial infection in the cause and progression of OLP $[23,24]$. To date, no dysbiosis has yet proven the causality of OLP [25]. On the other hand, there has not been much attention to the bacterial community or dysbiosis of OLP patients during their steroid treatment. With regard to the present results, the numbers and species of the oral microbial were greatly affected by dexamethasone treatment for 4 weeks. The effect was positive for reducing the relative periodontitis risk. Therefore, the OLP patients who received steroid therapy developed new healthy normal microflora through intensive oral hygiene management or probiotics to ameliorate microbial dysbiosis [26]. 
This study has some limitations in that the results did not demonstrate whether the improvement in OLP symptoms was due to the effect of dexamethasone gargle since there was the absence of a negative control showing no improvement in OLP or a positive control without the history of OLP. Due to the nature of the pilot study, we could not include sufficient patients with various populations, various concentrations, and types of mouthrinse. Furthermore, some unexplored variables can have a significant influence on the oral environment. For example, the use of probiotics and natural compounds can modify the clinical and microbiological parameters [27,28]. Therefore, they could also have an effect in patients affected with lichen planus. These variables should be considered in future clinical trials.

\section{Conclusions}

In this present study, most patients had a changed microbial community composition even though quantitative changes in oral microbial species were not found. Our results indicated that the composition of some periodontopathic bacteria changed positively after 4 weeks of gargling with $10 \mathrm{~mL}$ of $0.05 \%$ dexamethasone. Therefore, clinicians should consider that dexamethasone was affected oral bacteria. Further clinical study should be conducted with periodontitis patients.

Supplementary Materials: The following are available online at https:/ /www.mdpi.com/article / 10.3390/app11146286/s1, Table S1: Quantitative changes in oral microbial species of oral lichen planus patients.

Author Contributions: This research was made possible by the personal contributions of the following persons: J.-K.K. for writing original draft preparation, S.-Y.P. and P.-Y.Y. for conceptualization and methodology. J.-K.K. and P.-Y.Y. performed the data curation and the statistical analysis, K.-G.H. performed software support and financial support. All authors have read and agreed to the published version of the manuscript.

Funding: This research was supported by a grant of the Korea Health Technology R \& D Project through the Korea Health Industry Development Institute, funded by the Ministry of Health and Welfare, Republic of Korea (grant number: HI20C0013).

Institutional Review Board Statement: This study was reviewed and approved by the Institutional Review Board at Seoul National University Bundang Hospital (No. B-1704-393-305).

Informed Consent Statement: Written informed consent was obtained from all participants) to publish this paper.

Data Availability Statement: The data presented in this study are available on request from the corresponding author.

Conflicts of Interest: All the authors of this work wish to disclose that there are no financial or other conflicts of interest that might have biased the scientific information in this article.

\section{References}

1. Lodi, G.; Scully, C.; Carrozzo, M.; Griffiths, M.; Sugerman, P.B.; Thongprasom, K. Current controversies in oral lichen planus: Report of an international consensus meeting. Part 1. Viral infections and etiopathogenesis. Oral Surg. Oral Med. Oral Pathol. Oral Radiol. Endodontol. 2005, 100, 40-51. [CrossRef]

2. Sugerman, P.B.; Savage, N.W. Oral lichen planus: Causes, diagnosis and management. Aust. Dent. J. 2002, 47, 290-297. [CrossRef]

3. Masaki, M.; Sato, T.; Sugawara, Y.; Sasano, T.; Takahashi, N. Detection and identification of non-Candida albicans species in human oral lichen planus. Microbiol. Immunol. 2011, 55, 66-70. [CrossRef]

4. Levin, C.; Maibach, H.I. Topical corticosteroid-induced adrenocortical insufficiency: Clinical implications. Am. J. Clin. Dermatol. 2002, 3, 141-147. [CrossRef]

5. Hegarty, A.M.; Hodgson, T.A.; Lewsey, J.D.; Porter, S.R. Fluticasone propionate spray and betamethasone sodium phosphate mouthrinse: A randomized crossover study for the treatment of symptomatic oral lichen planus. J. Am. Acad. Dermatol. 2002, 47, 271-279. [CrossRef] [PubMed]

6. Gibson, N.; Ferguson, J.W. Steroid cover for dental patients on long-term steroid medication: Proposed clinical guidelines based upon a critical review of the literature. Br. Dent. J. 2004, 197, 681-685. [CrossRef] 
7. Lodi, G.; Manfredi, M.; Mercadante, V.; Murphy, R.; Carrozzo, M. Interventions for treating oral lichen planus: Corticosteroid therapies. Cochrane Database Syst. Rev. 2020, 2, CD001168. [CrossRef] [PubMed]

8. Scattarella, A.; Petruzzi, M.; Ballini, A.; Grassi, F.R.; Nardi, G.M. Oral lichen planus and dental hygiene: A case report. Int. J. Dent. Hyg. 2010, 9, 163-166. [CrossRef] [PubMed]

9. González-García, A.; Diniz-Freitas, M.; Vila, P.G.; Blanco-Carrión, A.; Garcia-Garcia, A.; Gándara-Rey, J. Triamcinolone acetonide mouth rinses for treatment of erosive oral lichen planus: Efficacy and risk of fungal over-infection. Oral Dis. 2006, 12, 559-565. [CrossRef]

10. Mirsepasi, H.C.; Persson, S.; Struve, C.; Andersen, L.O.B.; Petersen, A.M.; Krogfelt, K.A. Microbial diversity in fecal samples depends on DNA extraction method: easyMag DNA extraction compared to QIAamp DNA stool mini kit extraction. BMC Res. Notes 2014, 7, 50. [CrossRef]

11. Takeshita, T.; Nakano, Y.; Kumagai, T.; Yasui, M.; Kamio, N.; Shibata, Y.; Shiota, S.; Yamashita, Y. The ecological proportion of indigenous bacterial populations in saliva is correlated with oral health status. ISME J. 2008, 3, 65-78. [CrossRef]

12. Kim, S.-J.; Rim, D.; Heo, J.U.; Cho, H.-J. Possibility of predicting missing teeth using deep learning: A pilot study. J. Korean Acad. Oral Health 2019, 43, 210-216. [CrossRef]

13. Aas, J.A.; Paster, B.J.; Stokes, L.N.; Olsen, I.; Dewhirst, F.E. Defining the Normal Bacterial Flora of the Oral Cavity. J. Clin. Microbiol. 2005, 43, 5721-5732. [CrossRef]

14. Ballini, A.; DiPalma, G.; Isacco, C.G.; Boccellino, M.; Di Di Domenico, M.; Santacroce, L.; Nguyễn, K.C.; Scacco, S.; Calvani, M.; Boddi, A.; et al. Oral Microbiota and Immune System Crosstalk: A Translational Research. Biology 2020, 9, 131. [CrossRef] [PubMed]

15. Inchingolo, F.; Martelli, F.S.; Isacco, C.G.; Borsani, E.; Cantore, S.; Corcioli, F.; Boddi, A.; Nguyễn, K.C.; De Vito, D.; Aityan, S.K.; et al. Chronic Periodontitis and Immunity, Towards the Implementation of a Personalized Medicine: A Translational Research on Gene Single Nucleotide Polymorphisms (SNPs) Linked to Chronic Oral Dysbiosis in 96 Caucasian Patients. Biomedicines 2020, 8, 115. [CrossRef] [PubMed]

16. Lundström, I.M.; Anneroth, G.B.; Holmberg, K. Candida in patients with oral lichen planus. Int. J. Oral Surg. 1984, 13, 226-238. [CrossRef]

17. Riggio, M.P.; Lennon, A.; Wray, D. Detection of Helicobacter pylori DNA in recurrent aphthous stomatitis tissue by PCR. J. Oral Pathol. Med. 2000, 29, 507-513. [CrossRef] [PubMed]

18. Shimoyama, T.; Horie, N.; Kato, T.; Kaneko, T.; Komiyama, K. Helicobacter pylori in oral ulcerations. J. Oral Sci. 2000, 42, 225-229. [CrossRef]

19. Bornstein, M.M.; Hakimi, B.; Persson, G.R. Microbiological Findings in Subjects With Asymptomatic Oral Lichen Planus: A Cross-Sectional Comparative Study. J. Periodontol. 2008, 79, 2347-2355. [CrossRef]

20. Holmstrup, P.; Schiøtz, A.W.; Westergaard, J. Effect of dental plaque control on gingival lichen planus. Oral Surg. Oral Med. Oral Pathol. 1990, 69, 585-590. [CrossRef]

21. Backman, K.; Jontell, M. Microbial-associated oral lichenoid reactions. Oral Dis. 2007, 13, 402-406. [CrossRef] [PubMed]

22. Brasil-Oliveira, R.; Cruz, Á.A.; Sarmento, V.A.; Souza-Machado, A.; Lins-Kusterer, L. Corticosteroid Use and Periodontal Disease: A Systematic Review. Eur. J. Dent. 2020, 14, 496-501.

23. Wang, K.; Lu, W.; Tu, Q.; Ge, Y.; He, J.; Zhou, Y.; Gou, Y.; Van Nostrand, J.; Qin, Y.; Li, J.; et al. Preliminary analysis of salivary microbiome and their potential roles in oral lichen planus. Sci. Rep. 2016, 6, 22943. [CrossRef] [PubMed]

24. Choi, Y.S.; Kim, Y.; Yoon, H.-J.; Baek, K.J.; Alam, J.; Park, H.K.; Choi, Y. The presence of bacteria within tissue provides insights into the pathogenesis of oral lichen planus. Sci. Rep. 2016, 6, 29186. [CrossRef]

25. Baek, K.; Choi, Y. The microbiology of oral lichen planus: Is microbial infection the cause of oral lichen planus? Mol. Oral Microbiol. 2017, 33, 22-28. [CrossRef]

26. Allaker, R.P.; Stephen, A.S. Use of Probiotics and Oral Health. Curr. Oral Health Rep. 2017, 4, 309-318. [CrossRef]

27. Butera, A.; Gallo, S.; Maiorani, C.; Molino, D.; Chiesa, A.; Preda, C.; Esposito, F.; Scribante, A. Probiotic Alternative to Chlorhexidine in Periodontal Therapy: Evaluation of Clinical and Microbiological Parameters. Microorganisms 2020,9 , 69. [CrossRef]

28. Costa-Pinto, A.; Lemos, A.; Tavaria, F.; Pintado, M. Chitosan and Hydroxyapatite Based Biomaterials to Circumvent Periprosthetic Joint Infections. Materials 2021, 14, 804. [CrossRef] 